\title{
The New Normal
}

\section{Market Cooperation in the Mobile Payments Ecosystem}

Henningsson, Stefan; Hedman, Jonas

\author{
Document Version \\ Accepted author manuscript
}

Published in:

Electronic Commerce Research and Applications

DOI:

10.1016/j.elerap.2015.03.005

Publication date:

2015

\section{License \\ CC BY-NC-ND}

Citation for published version (APA):

Henningsson, S., \& Hedman, J. (2015). The New Normal: Market Cooperation in the Mobile Payments Ecosystem. Electronic Commerce Research and Applications, 14(5), 305-318. [603].

https://doi.org/10.1016/j.elerap.2015.03.005

Link to publication in CBS Research Portal

\section{General rights}

Copyright and moral rights for the publications made accessible in the public portal are retained by the authors and/or other copyright owners and it is a condition of accessing publications that users recognise and abide by the legal requirements associated with these rights.

Take down policy

If you believe that this document breaches copyright please contact us (research.lib@cbs.dk) providing details, and we will remove access to the work immediately and investigate your claim. 


\section{The New Normal: Market Cooperation in the Mobile Payments Ecosystem}

\section{Stefan Henningsson and Jonas Hedman}

Journal article (Post print version)

CITE: The New Normal : Market Cooperation in the Mobile Payments Ecosystem. / Henningsson, Stefan; Hedman, Jonas. In: Electronic Commerce Research and Applications, Vol. 15, No. 5, 2015, p. 305-318.

DOI: 10.1016/j.elerap.2015.03.005

Uploaded to Research@CBS: December २016

(C) 2016. This manuscript version is made available under the CL-BY-NC-ND 4.0 license http://creativecommons.org/licenses/by-nc-nd/4.0/ 


\title{
THE NEW NORMAL: MARKET COOPERATION \\ IN THE MOBILE PAYMENT ECOSYSTEM
}

\author{
Jonas Hedman (corresponding author) \\ Department of IT Management \\ Copenhagen Business School \\ Howitzvej 60, 2000 Frederiksberg, Denmark \\ Email: jh.itm@cbs.dk \\ Stefan Henningsson \\ Department of IT Management \\ Copenhagen Business School \\ Howitzvej 60, 2000 Frederiksberg, Denmark \\ Email:sh.itm@cbs.dk
}

Last revised: March 2, 2015

\begin{abstract}
The introduction of mobile payments is one of many innovations that are changing the payment market. This change involves new payment service providers entering this lucrative market, and meanwhile, the existing stakeholders are trying to defend their oligopolistic positions. The mobile payment market cooperation (MPMC) framework that this article develops shows how the digitalization of payments, as a technology innovation, affects the competition and collaboration among traditional and new stakeholders in the payment ecosystem at three levels of analysis. We do this by integrating theories of market cooperation with the literatures on business and technology ecosystems. The MPMC framework depicts technology-based market cooperation strategies in the context of recent battles in the mobile payments ecosystem. In these battles, the competitors can use technology either in defensive build-and-defend strategies to protect market position, or in offensive battering-ram strategies for ecosystem entry or position improvement. Successful strategies can lead to: (1) Ricardian rents, based on operational efficiency advantages traceable to the firm's position relative to suppliers and monopoly power; and (2) Bainian rents, resulting from the extent the firm is able to resist price competition in the market. We validate the framework that we propose through three case studies of technology-based market cooperation in the mobile payments ecosystem.
\end{abstract}

Keywords. Case study, iZettle, market cooperation, mobile payment, payment ecosystem, payment markets, PayPal, SMS payment.

Acknowledgments. This work was carried out with the support of the Copenhagen Finance IT Region (www.cfir.dk), and was funded by the Danish Enterprise and Construction Authority, under Grant \#ERDFH-09-0026. 
This is the pre-edited version of "Hedman, J., and Henningsson, S. (2015) "The new normal: Market cooperation in the mo1 bile payments ecosystem". Electronic Commerce Research and Applications, 14, 5, 305-318".

\section{INTRODUCTION}

Payments have become a hot spot for digital innovation (McKinsey, 2014b). Mobile phone manufactures, telecom operators, payment service providers, software companies, and technology start-ups all are entering the payment market (Gartner, 2014; McKinsey, 2014b). It is not only the well-known Internet giants, such as Google, Facebook, and Apple, and the early payment entrepreneurs such as Square, PayPal and iZettle anymore. There now are more there are more 12,000 start-ups moving into the payment services market (McKinsey, 2014b). This is reshaping the industry and banks have been trying to fight off the competitors by using their existing market positions and IT infrastructures. For instance, Dansk Bank (2015) in Denmark responded to changes in the market by launching a mobile peer-to-peer payment app called "Mobile Pay". After only eighteen months, the payment app was adopted by about $40 \%$ of the Danish population.

One of the factors explaining the pace of innovation is that payment fees, even though the fees are declining per transaction, still are among the most important sources of revenues for banks. According to McKinsey (2014a), the global annual revenues from payments will reach by 2018 US $\$ 2.3$ trillion and account for $43 \%$ of all banking services revenues. Another factor is the ongoing digitization of banking and payments. In particular, the mobile phone now plays a central role in this transformation and it has been suggested that "banks should have a 'mobile first' philosophy, in which products and processes are completely redesigned for mobile, after which they are translated to Internet and branches" (McKinsey, 2014a).

Due to digital convergence with mobile technologies, payments have become one of society's most innovative and dynamic sectors, with fierce technology-based competition for market position (Ondrus and Lyytinen, 2011). Banks all over the world are talking about the technology-led competition as the "new normal" or the "new standard", referring to that the industry has started to display competitive dynamics that are typical of high-tech industries rather that traditional financial industries (cf. Lee et al., 2010). For example, digital payments are information goods with near to zero marginal cost and frequently strong direct network effects (Bakos and Brynjolfsson, 1999; Ferguson, 2009). Most payments compete in two-sided markets where different costumer groups - payers and payees - 
This is the pre-edited version of "Hedman, J., and Henningsson, S. (2015) "The new normal: Market cooperation in the moz bile payments ecosystem”. Electronic Commerce Research and Applications, 14, 5, 305-318”.

are matched through some means of digital intermediation (Evans et al., 2006; Rochet and Tirole, 2003; Shapiro and Varian, 2013). Thus, the dynamics of payment markets are similar to mobile industries and characterized by tension between competition and collaboration among stakeholders

(Ghazawneh and Henfridsson, 2012; Selander et al., 2010). While some of the stakeholders are direct competitors, they are also mutually dependent on the success of the industry as a whole and thus are forced into collaboration with other entities.

However, the payment market also displays characteristics that set it apart from other digital industries. The payment market is characterized by strong regulatory framework and oligopoly (Ferguson, 2009). Because of its high societal impact, regulatory agencies typically have a strong interest in influence how stakeholders assume positions within the market. In addition, payment markets have a long history of collaboration between the stakeholders, where change is frequently is achieved by consensus and joint efforts rather than an innovation arms race. There are limitations in the conceptual understanding of how these distinct characteristics of payment markets influence how firms compete in payment markets. Thus, contributing towards an increased understanding of the effects of digitalization of payments per se, also to digital ecosystem dynamics in general, we seek to explain how the digitization of payments, as a technology innovation, affects competition and collaboration among traditional and new stakeholders of the payments ecosystem.

We do this by developing the mobile payment market cooperation (MPMC) framework, which is based on an integration of market cooperation theory ${ }^{1}$ (Makadok, 2003, 2011) and ecosystems theory from the business technology domain (Adomavicius et al., 2007; Basole and Karla, 2011; Moore, 1996; Selander et al., 2013).

Market cooperation theory is based on the view that some markets and market positions restrains price rivalry, thereby allowing firms to profit at the expense of their customers. The profit generating mechanism of market position is particularly relevant in the typical two-sided market (Rochet and

\footnotetext{
${ }^{1}$ In his review of theories of profit, Makadok (2011) refer to this group of theories as market collusion theory. The term 'collusion' has a very strong emphasis of the competitive dimension of market positioning, which we consider not matching the more collaborative sentiment of the ecosystem perspective and the empirical context in this study. The Danish payment market is characterized by on a long history of collaboration between governmental agencies and financial institutions. Therefore, throughout this paper, we refer to the theories that relate to firm's market positioning as market cooperation theory, with cooperation being the term to denote firm collaboration and competition in markets to achieve coopetitive and beneficial outcomes.
} 
This is the pre-edited version of "Hedman, J., and Henningsson, S. (2015) "The new normal: Market cooperation in the mo3 bile payments ecosystem". Electronic Commerce Research and Applications, 14, 5, 305-318".

Tirole, 2003; Stabell and Fjeldstad, 1998), where the platform owner controls the cluster of stakeholders and captures a large share of the profit, high network effects that frequently lead to tippy markets, and scale advantage through high fixed and near zero marginal costs (Gawer and Henderson, 2007; Shapiro and Varian, 2013).

We use the business ecosystem as the unit of analysis, since previous research has concluded that mobile technological developments cannot be viewed in isolation. Thus, one has to consider the system and infrastructure they are part of (Adomavicius et al., 2007). In similar line of research, Basole and Karla (2011) propose that the organization of mobile industries, such as mobile payments, is more appropriately conceived as an ecosystem. One example is the direct credit transfer (bank account to bank account) from a mobile phone. It involves mobile phones, mobile phone operators, mobile bank applications developed by third party software providers, internal banking systems, and interbank processing provided by central banks.

Drawing upon three embedded case studies from the Danish payment ecosystem, we illustrate how different market cooperation strategies are used in the ecosystem and how turbulence is a recurring pattern in the evolution of socio-technical ecosystems (see e.g. Henningsson and Henriksen, 2011). We show that established competitors apply the defensive strategy of build-and-defend and new competitors use the offensive strategy of a battering-ram.

The reminder of the article is organized as follows. In Section 2, we develop the MPMC framework by integrating market cooperation strategies and ecosystem theories. Then, in Section 3, we outline our case study approach, including data collection and analysis. Following this, in Section 4, we present our three illustrative case studies from the Danish payments market. This is followed by a discussion of the proposed framework's validity in Section 5. Finally, we discuss implications for theory, practice, and future research in Section 6.

\section{MOBILE PAYMENT MARKET COOPERATION FRAMEWORK}

We develop the MPMC framework in three steps. First, we discuss how technology can be used in market cooperation strategies. We identify two generic strategies. One is a defensive strategy that we label the build-and-defend strategy. Established competitors use it to fight off new entrants. The 
This is the pre-edited version of "Hedman, J., and Henningsson, S. (2015) "The new normal: Market cooperation in the mo4 bile payments ecosystem”. Electronic Commerce Research and Applications, 14, 5, 305-318”.

other is an offensive strategy that we label the battering-ram strategy. New competitors that are aiming to enter the market use this strategy. Second, we introduce the concept of the digital ecosystem. The digital ecosystem view, building on the idea of a business ecosystem, emphasizes the relationship between technology and strategy, which otherwise cannot be fully understood by approaching each as an isolated unit. Third, we synthesize the market cooperation strategies and ecosystems literature into an integrated explanatory framework for technology-based market cooperation strategies that is applicable to the mobile payment ecosystem.

\subsection{Technology as a Basis for Market Cooperation Strategy}

To understand how any technology, including payment technology, creates value for an organization, the technology has to be linked to the organization's value-creation mechanisms. Makadok $(2003,2011)$ offers a useful categorization of the major theories in strategic management. He organized them by their causal profit mechanisms. They are the means through which money moves from a customer to a vendor in exchange for goods or services, generating net profit in the meantime. This categorization views the numerous theories of strategic management through four value mechanisms: collusion, governance, competence, and flexibility.

Theories for market cooperation strategy, addressing how firms collaborate and compete to assume positions in a market space, relate to the collusion profit mechanism. Fundamental for these theories is the observation that a firm's choice of and position in an industry, it turns out, are important factors for performance. For a firm to change its market position, it must have the ability to cooperate with other stakeholders in a way that enables it to exert power over its suppliers and customers. Below, we will define the objectives and mechanisms of market cooperation strategies. Then, we will discuss how technology can be used in defensive and offensive strategies. 
This is the pre-edited version of "Hedman, J., and Henningsson, S. (2015) "The new normal: Market cooperation in the mo5 bile payments ecosystem”. Electronic Commerce Research and Applications, 14, 5, 305-318”.

Market cooperation and firm profit. Market cooperation theories suggest that "market power is necessary for an industry's participants to be able to recover fixed investments and create long-term returns on equity that exceed that of firms in other industries" (Drnevich and Croson, 2013). From this perspective, market concentration and barriers to entry that limits the competition on price and leads to increased average industry profit (Makadok, 2011).

Common for this category of theories is an explicit or implicit view on management as market positioning, tailoring firm strategy to create or exploit unique industry characteristics. Establishing and defending an attractive position in the marketplace enables a firm to either gain pricing power towards consumers or gain bargaining power towards suppliers. Following the analysis of Makadok (2003, 2011) and Drnevich and Croson (2013), the economic profit mechanisms for the firm in this perspective include both operational efficiency advantages, so called Ricardian rents (Ricardo, 1817). These are traceable to market power and position relative to suppliers and monopoly-related rents (Bain, 1956). This enables such firms to resist price competition from competitors.

Defensive strategy: build-and-defend. Drawing on Drnevich and Croson (2013), we identify two principle uses of technology for market cooperation strategies: (1) the build-and-defend strategy, and (2) the battering-ram strategy. We analyze the first strategy in terms of strategic options for existing stakeholders in an industry. We discuss the latter strategy as an option for existing firms in the market and new entrants that want to change their market position. Table 1 summarizes the two strategies and their options for technology-based market cooperation strategy in mobile ecosystems.

\section{INSERT TABLE 1 ABOUT HERE}

The build-and-defend strategy is based on the logic that access to technology can act as defense for a particular market position or a barrier for market entry. In the establishment of barriers of entry, the existing stakeholders in an industry have a typical interest in collaborative strategies to manage technology in a way that hinders new competitors to enter. Fewer competitors in an industry generally leads to decreased price competition and, in the end, increased average profit for the existing participants (Drnevich and Croson, 2013). From the viewpoint of an individual business unit, the most profitable position is when the technology somehow can grant the business unit a monopoly position that 
This is the pre-edited version of "Hedman, J., and Henningsson, S. (2015) "The new normal: Market cooperation in the mo6 bile payments ecosystem”. Electronic Commerce Research and Applications, 14, 5, 305-318”.

allows one-sided decisions on pricing. There are two ways technology can contribute towards such positions in the industry: by level of capital investment, and by technology access.

First, Drnevich and Croson (2013) put forward that large-scale capital investments in technology can serve as barriers to market entry, because of their large initial capital requirements and uncertain prospects for their recovery. This will be true if competing in an industry requires substantial initial investment in technology resources and ongoing investment to maintain complementary capabilities.

Some parts of the payment industry are characterized by very high initial technology investment costs. For example, the banks and payment card providers need to build the large interbank transfer systems and card clearing systems that are the basis for payments. These investments signal commitment on the part of the incumbent to defend its market (Drnevich and Croson, 2013). The incentive for incumbent commitment is to discourage potential rivals to enter into the market, even though it would be technologically and financially possible for them to replicate the incumbent's investments.

Second, for the tech payment industry, not only the size of the investment capital required, but also access to technology can act as a barrier. Some technology is proprietary, such as interbank transfer systems, which are unique to an individual firm or to a small cluster of businesses. Establishment of de facto standards and technical patents are well-established strategies to protect a firm's market position in the digital marketplace (Shapiro and Varian, 2013).

Within the payment industry, it is also possible to set up alliances or temporary collaboration agreements that hinders new competitors to enter the industry by limiting the technology access of other potential collaborators. An example is the Payment Card Institute, which governs the use of the chip that is embedded in payment cards. So for the overall success of the ecosystem, it might be in the interest of all in the marketplace to block the entry of new competitors by refusing to give them access to essential technology.

Offensive strategy: the battering-ram. While technologies can be employed to hinder new entrants, technology can also be used as a battering-ram to gain a foothold in a market or to break an especially profitable position of a rival. History is replete with examples of how new competitors have drawn on disruptive technological innovations to penetrate or bypass existing ecosystems 
This is the pre-edited version of "Hedman, J., and Henningsson, S. (2015) "The new normal: Market cooperation in the mo7 bile payments ecosystem”. Electronic Commerce Research and Applications, 14, 5, 305-318”.

(Christensen and Overdorf, 2000). For instance, early strategic ITs provided many new entrants important advantages that enabled them to out-compete incumbents with new PC-based IT solutions. For many low-cost airlines, for example, the utilization of the Internet for ticket sales enabled their customers to both bypass an existing, potentially impeding ecosystem of incumbent airlines and travel agencies. This also enabled the new entrants to lower the total operating cost of issuing and handling ticketing. This slowly yielded a competitive edge for the new entrants over the incumbents.

For the new entrants in an industry, a decision to use technology as a battering-ram for market entry is essentially a decision related to the level of technological compatibility that exists in the market (Shapiro and Varian, 1998). The first option is to attempt entry with a technology that is compatible with existing technologies, and seeking to establish collaborative relationships with others who control the technology. Related to this is to compete with other firms that provide similar products or services. This includes an iPhone app that competes with any other iPhone app that provides similar functionality, or an Android-based smartphone that competes with other Android phones. Both have to come up with technological innovations that make the offers desirable compared to other existing offers. This strategy is in the category of payments offered by some vendors of payment card readers that seek to establish collaborative relationships with stakeholders who potentially control technologies and competitive relationships with ecosystem stakeholders who are providing similar products or services.

The second option is to enter through technology strategies involving incompatible, or close to incompatible technologies that are based on new technology regimes (Shane, 2001). In payments, Bitcoin has opened up a new type of competitive regime. Mobile technologies, meanwhile, are competing effectively competing with fixed-line telecom ecosystems, but such regimes do not automatically lead to complete incompatibility: total compatibility and total incompatibility are simplifications of what we observe in most economies. However, with the introduction of mobile technologies, new business ecosystems also have emerged that would not have been possible before. And firms in the existing fixed-line telecom ecosystem have only partly managed to figure out the transition to the new technology regime. 
This is the pre-edited version of "Hedman, J., and Henningsson, S. (2015) "The new normal: Market cooperation in the mo8 bile payments ecosystem”. Electronic Commerce Research and Applications, 14, 5, 305-318”.

\subsection{Technology Business and Technology Ecosystems}

Characteristics of ecosystems. The term ecosystem originally comes from biology (Tansley, 1935). Moore (1996, p.26) defined a business ecosystem as:

"an economic community supported by a foundation of interacting organizations and individuals - the organisms of the business world. The economic community produces goods and services of value to customers, who are themselves members of the ecosystem. The member organisms also include suppliers, lead producers, competitors, and other stakeholders. Over time, they coevolve their capabilities and roles, and tend to align themselves with the directions set by one or more central companies."

The ecosystem concept has been introduced to a number of scientific domains, including business (Selander et al., 2013), technology (Messerschmitt and Szyperski, 2005), information (Moore, 1996), and payments (May et al., 2008).

More generally, an ecosystem is defined as a co-opetitive environment in which symbiotic relationships are formed to create mutual value for its stakeholders (Basole, 2009; Selander et al., 2010; Selander et al., 2013). In the literature, four features of ecosystems stand out. First, an ecosystem is characterized by simultaneous competition and cooperation, so called co-opetition (Brandenburger and Nalebuff, 2011; Walley, 2007). Micro-level analysis depicts some stakeholders as direct competitors, while macro-level analysis depicts the same stakeholders as mutually dependent on the success of the ecosystem as a whole. In some setting there may be some degree of collaboration with other stakeholders in the ecosystem, resulting in strategic networks.

Second, a key success factor for a prosperous ecosystem is the relationship among the stakeholders in the ecosystem. For the individual stakeholders, this is partly a matter of managing resource dependencies. Stakeholders in the ecosystem that control important resources can exercise power over other stakeholders and can capture a larger part of the ecosystem's total revenues. However, if the stakeholders that control key resources hold the "keystone advantage" are exercising too much pressure relative to the other stakeholders, it might be fatal to the ecosystem as a whole, and as a consequence, may damage the business of the keystone stakeholders as well (Iansiti and Levien, 2004).

Third, ecosystems have observable differences. For example, within a business ecosystem, certain stakeholders can have closer relations than other stakeholders. One can even talk about ecosystems of ecosystems. As an analytical construct, this leads to a problem of stakeholder inclusion: which level 
This is the pre-edited version of "Hedman, J., and Henningsson, S. (2015) "The new normal: Market cooperation in the mo9 bile payments ecosystem”. Electronic Commerce Research and Applications, 14, 5, 305-318”.

of analysis to use and where to draw the borders for an ecosystem? The problem of inclusion is not unique to ecosystems, but is a classical problem in social theory that has been discussed extensively in prior literature (March and Simon, 1958). Weick (1969) argues that this is partly due to the fact that it is activities, not people, who are organized. Any individual is only partly included in the organization. Consequently, individuals can be both part of an organization and its environment. Similarly, an organization can be a stakeholder in many ecosystems. The problem is accentuated in the analysis of an ecosystem, where most of the organizations are involved in more than one set of related coordinated activities.

Pfeffer and Salancik (2003) also discuss organized activities. They argue that the problem of where an organization begins and ends disappears when it is approached as a set of coordinated activities. A similar reasoning can be applied to ecosystems, but then from the perspective of co-opetive relationships. However, from this position the issue arises of how to handle the within-ecosystems clusters of stakeholders that are more tightly connected. Within ecosystems, competitors might form partnerships, alliances, networks and other formal and informal cluster formation that as a group have co-opetive relations to other clusters. An example is when two rival standards attract groups of proponents and adaptors. To capture this level of co-opetive interactions, a meso-level of analysis is required. The meso-level is able to depict situations where more than one, but not all competitors in an ecosystem form business clusters and have co-opetive relations with other business clusters.

The fourth typical characteristic of ecosystems is that they are not stable, but are constantly evolving. Continuous adaptations in the relationships between ecosystem stakeholders across the micro, meso and macro-levels make ecosystems dynamic. The systemic properties of an ecosystem means that changes in one of the ecosystems entities will trigger responses and changes in other entities. As a consequence, "ecosystems are essentially defined by the active shaping of relationships between their members" (Selander et al. 2010, p. 2). Given the co-opetive nature of the relationships among ecosystem stakeholders, the changes respond to the need to capture business value in a way that nurtures the value appropriation capabilities of other stakeholders in the ecosystem. 
This is the pre-edited version of "Hedman, J., and Henningsson, S. (2015) "The new normal: Market cooperation in the mp0 bile payments ecosystem”. Electronic Commerce Research and Applications, 14, 5, 305-318”.

Technology-based payment ecosystems. Previous research has observed that ecosystems transform rapidly along with technological innovations that alter conditions for the business landscape (Evans et al., 2006; Yoo et al., 2008; Zammuto et al., 2007). New technology generations are fundamentally reshaping the traditional logic, as business processes become intertwined with surrounding technology ecosystems (Basole, 2009). This is also true in the payment ecosystems.

We conceptualize a payment ecosystem as one that exists in a fusion relation (Sawy, 2003) to technologies, in which the technologies form part of a technology ecosystem. Adomavicius et al. (2007, p. 201) define a technology ecosystem as "system of interrelated technologies that influence each other's evolution and development." The definition is based on the view of evolving components of complex technologies as being mutually interdependent (Henderson and Clark, 1990; Iansiti and Khanna, 1995). Consequently, from the consumer side, the selection of a specific technology is associated with a decision to join a particular business network that operates in a specific technological regime with interoperable technologies (Shane, 2001).

Markets based on products or services where compatibility is a key factor are characterized by system-based competition (Katz and Shapiro, 1994). In these markets, compatible products complement each other and create higher value as a system, such as ATMs and payment cards, and payment terminals and credit cards. An example outside the payment domain includes nuts and bolts, which together provide fastening services. Also, in the mobile handset and telecommunication network domain, smartphones and apps are examples of highly complementary products.

Two products are defined to be complementary products when changes in the activity levels of one of the products (e.g., sales, functionality, and ease of use) affect the marginal returns to changes in the activity levels of the other product as well (Milgrom and Roberts, 1990). Complementary products mutually depend on each other and reinforce each other's performance outcomes. Customers prefer to purchase complementary technologies as a system of complements rather than as stand-alone products because technologies must interoperate (Lee et al., 2010). The value of the system is greater than the sum of the values of the individual products (Tanriverdi and Lee, 2008). 
This is the pre-edited version of "Hedman, J., and Henningsson, S. (2015) "The new normal: Market cooperation in the mp1 bile payments ecosystem”. Electronic Commerce Research and Applications, 14, 5, 305-318”.

For the payment ecosystem stakeholders, the connected relationship between business and strategy means that the collaborative and competitive strategies of the individual business units and business clusters in ecosystem are inseparable from the strategic adoption of technology. The inseparability of business and technology evolution, as a result, can be attributed to the systemic properties of technologies on micro, meso, and macro-levels of the ecosystem.

\subsection{The Mobile Payment Market Cooperation (MPMC) Framework}

A payment ecosystem, then, is an ecosystem in which business and technology strategies are inseparable. As a result, technology can be used in defensive and offensive market strategies at different levels in the ecosystem, including the micro, meso and macro-levels.

The MPMC framework integrates the possible use of technology to enact market strategies with the three levels of ecosystem analysis. (See Figure 1.)

\section{INSERT FIGURE 1 ABOUT HERE}

At the core of the MPMC framework is the idea of technical compatibility, which permits technological innovations to be built into technical systems. In a market with mobile technologies, technical compatibility makes it possible for firms to execute their strategies in the market. Competition and collaboration exist at all three levels, and so do classes of compatible and incompatible technologies. Consequently, technology-based market cooperation strategy in mobile payment ecosystems can be understood as a three-level battle between defensive and offensive technology-based strategies:

- On the micro-level, individual business units compete with market cooperation strategies based on proprietary technologies, for instance, the traditional card terminals that you find at most cashiers versus the mobile dongle card readers.

- On the meso-level, formal and informal strategic networks and alliances are formed as a result of stakeholders joining forces in clusters to compete with other clusters of stakeholders using market cooperation strategies based on shared technologies, for instance, the entrance of mobile operators in the payment sector providing SMS payments. 
This is the pre-edited version of "Hedman, J., and Henningsson, S. (2015) "The new normal: Market cooperation in the mp2 bile payments ecosystem”. Electronic Commerce Research and Applications, 14, 5, 305-318”.

- On the macro-level, the ecosystem of interdependent stakeholders will compete with other ecosystems through market cooperation strategies based on technology regimes. For instance, stakeholders such as Bitcoin may threaten the entire industry.

Stakeholders in the payment ecosystem contribute to its technologies through innovation and adoption either in competitive or collaborative mode with other stakeholders. In the collaborative mode, stakeholders in the micro, meso or macro-levels will jointly innovate or adopt component, application or support technologies that will benefit the stakeholders in the collaboration. Conversely, in the competitive mode, stakeholders on the micro-level will innovate or adopt component, application, or support technologies that will benefit the specific stakeholder. Meso-level adoption is a situation involving a combination of the competition and collaboration modes.

In the MPMC framework, macro-level ecosystem technological and business evolution is the result of the ecosystem stakeholders' decisions to adopt compatible or incompatible technology strategies. Strategy at the ecosystem level can be decided upon by one single business organization in an ecosystem that is heavily dominated by one single stakeholder. However, as illustrated by our case studies below, thus far the evolution of the payment ecosystem has been a more federated, distributed or emergent decision.

\section{METHOD}

This article uses an exploratory approach on payment ecosystems with three embedded cases of mobile payment innovations and their impacts. The aim of the case study is to illustrate the framework in the context of payments in Denmark. We will focus on how existing stakeholders and new entrants use technology for market positioning.

\subsection{Research Approach and Case Selection}

Research on market cooperation and business or technological ecosystems is often carried out independently for one topic versus the other. This is one reason for the limited understanding of the link between technological strategy and business strategy in mobile ecosystems (Drnevich and Croson (2013). This is also one of our arguments for selecting the case study approach, as the case setting allows for a rich multi-perspective exploration of a phenomena to understand how different theories 
This is the pre-edited version of "Hedman, J., and Henningsson, S. (2015) "The new normal: Market cooperation in the mp3 bile payments ecosystem". Electronic Commerce Research and Applications, 14, 5, 305-318".

translates into the domain. Another argument for the case study approach is that there may be unclear boundaries between the phenomenon of interest in a general sense and how things play out around it in industry. This seems to be true for the mobile payments ecosystem. In addition, the choice of a multiple case study strategy is a strength in this situation. The cases can be viewed as a series of experiments, allowing for replication rather than just sampling (Yin, 1984).

We achieved this with three cases whose findings are replicated across different levels of analysis. In practice, this means that each case is analyzed in relation to the framework and additional cases are used to challenge the insights gained from the previous cases. The insights grow with each case and allow for the emergence of theory based on a deeper and richer understanding of the underlying facts and circumstances. This type of empirical grounding gives a theory that is more likely to be free of the bias of the researcher (Eisenhardt, 1989), and that maintains a close correspondence between the theory and the data available to evaluate it. This is especially important in the early stages of research on a new topic, when it is not clear whether the research question is informed by existing theories. In this study, we focus on three technological innovations and their associated cooperation strategies that are being used for entry into the Danish payments market. The cases represent the micro-level, mesolevel, and macro-level of analysis. The cases include: iZettle, a payment dongle invented by a startup; SMS payment services from mobile operators ${ }^{2}$; and PayPal, which is a potential competitor.

\subsection{Data Collection and Analysis}

Because of the large number of stakeholders involved in an ecosystem, researching ecosystems is challenging. The payment ecosystem entails two additional challenges: the sensitive nature of the financial industry, and the ongoing battle between existing competitors and new entrants. The latter condition makes it highly interesting from a research perspective, but this condition also implies that getting access to the business strategies that are in the center of the ecosystem battle is difficult. In the case of the Danish payment ecosystem, the authors have been part of a large three-year research program on finance and information technology. All major national payment stakeholders participated in the program, which made access to our research informants possible.

\footnotetext{
${ }^{2}$ The choice of these three contenders is based on the current market situation in Denmark (Nationalbank, 2013). For instance, more contemporary payment technologies, such as NFC based solutions, do not currently exist in Denmark. Therefore, we had to include the older SMS payment service.
} 
This is the pre-edited version of "Hedman, J., and Henningsson, S. (2015) "The new normal: Market cooperation in the mp4 bile payments ecosystem”. Electronic Commerce Research and Applications, 14, 5, 305-318”.

For this article, we used material from documents, interviews and workshops as empirical sources. See Appendix 1 for a full listing of our data sources. The main sources are official documents from Denmark and the European Union on the payment ecosystem (Danmarks Nationalbank 2005, Kokkola 2010). These documents give an official description of the ecosystem and its stakeholders. Data regarding the three cases come from publicly available sources, such as annual reports, news stories and press releases, research articles, and web pages.

One of the authors also took part in six workshops on future payment technologies, organized by the financial industry in Denmark. Notes were taken during the workshops, which were later expanded after the session. Based on this initial understanding, semi-structured interviews with eight representatives from various stakeholders, such as financial institutions, mobile payment instrument providers, and government agencies, were asked to investigate specific aspects. These interviews were transcribed. The interviews and the workshops provided data to understand the relationships among the competing stakeholders, the role of technology innovations, and how the existing establishment has tried to fight them off.

Table 2 summarizes the measures taken to ensure reliability and validity. When analyzing the cases, the empirical observations were matched and compared with the MPMC framework and its concepts, using a case study-related pattern-matching technique (Yin 1984). Since our research is developed as case study research, we sought to develop theory rather than fit a theory to a population. As such, we used our empirical findings to validate our framework and its concepts related to the evolution of the payments ecosystem.

INSERT TABLE 2 ABOUT HERE

\section{THE MOBILE PAYMENT MARKET COOPERATION FRAMEWORK IN AC- TION}

In this section, we illustrate the MPMC framework and its concepts by discussing the entrance of three payment technologies, namely mobile card terminals, SMS payments, and PayPal, and how competition and collaboration emerged in the payment market. But, before doing so, we will provide a short description of the Danish payment ecosystem. 
This is the pre-edited version of "Hedman, J., and Henningsson, S. (2015) "The new normal: Market cooperation in the mp5 bile payments ecosystem". Electronic Commerce Research and Applications, 14, 5, 305-318".

\subsection{The Payment Ecosystem}

Denmark and most modern societies are dependent on payment systems, where economic agents, such as individuals or firms, carry out transactions of money. ${ }^{3}$ Mattias Persson, Head of Financial Stability, has stressed the importance of payment systems:

"In a modern economy, it is important that payments can be implemented safely and efficiently. From previously mainly having involved the change of ownership of banknotes and coins, payments have become increasingly complex and are currently usually performed with the help of various payment intermediaries. As a result, payment intermediation has become a service that is offered in a market, ..., which is used on a daily basis by households, companies and authorities" (Sveriges-Riksbank, 2013, p. 5).

In the payment ecosystem, there are banks and financial services firms that provide accounts, payment instruments, and other services to payers and payees. Besides the payers and payees, the key ecosystem stakeholders in Denmark are the two leading banks Dansk Bank and Nordea, ${ }^{4}$ the major clearinghouse for card payments NETS, the bankers association Finansrådet, and Danmarks National Bank. A summary of the key stakeholders and their roles is shown in Table 3.

\section{INSERT TABLE 3 ABOUT HERE}

The banks issue payment cards, set up accounts, settle payments, and provide human and technical interfaces to the payment system. NETS manages the national debit card Dankort, and the payment card clearinghouse for Dankort. It also controls most of the card terminals. NETS was owned by the banks and the central bank until Spring 2014. In addition, to this, NETS runs the national esecurity system, NEM-ID, and the national account system, NEM-Konto. The Senior Vice President Per Harald Strøm describes NETS' market position as “... people and societies depending on our in-

\footnotetext{
${ }^{3}$ Payments represent the process of transferring money from payer to payee, and involve payment instruments, payment processing, and payment settlement. Payment processing and settlement involve often one or several middlemen, who actually transfer the money between accounts. All payments are based on a payment instrument that includes a set of procedures enabling the transfer of money from the payer to the payee. There are several payment instruments and they can be divided into cash and non-cash payment instruments. Non-cash or electronic payments involve transfers of money between accounts that are mediated by third parties. This type of payment is referred to as provision-based payments. The payer or payee gives instructions to the bank to either transfer or collect money from an account and move it to another account. The most-used non-cash payments in the world are payment cards (debit or credit cards), credit transfers (account to account), and direct debits (account to account). Each payment instrument has its own characteristics and instructions. (Kokkola 2010, Danmarks Nationalbank 2005).

${ }^{4}$ Danish banks were among the first in the world to develop and invest in electronic payment services in the 1960s. The banks established PBS in 1968 to develop and deploy payment solutions. Then in 1983, PBS introduced the national debit card, the Dankort. NETS was formed in 2009 as a merger between Danish PBS Holding $\mathrm{A} / \mathrm{S}$ and Norwegian Nordito AS. The company processes almost all payment cards in Denmark.
} 
This is the pre-edited version of "Hedman, J., and Henningsson, S. (2015) "The new normal: Market cooperation in the mp6 bile payments ecosystem". Electronic Commerce Research and Applications, 14, 5, 305-318".

\section{frastructure."}

Finansrådet is a professional organization representing the banks, with the goal of creating good operating conditions for them banks so they can achieve profitable performance. They do this by "closely monitor the political processes and play an active and specific role in political decisionmaking that is relevant for the banks' business platform" (Finansrådet 2011a). Furthermore, it own SumClearing, a retail payments clearing system, which is operated by NETS.

Besides the national legal framework, international commercial law regulates the payments market. The United Nations Commission on International Trade Law and the World Trade Organization provide overarching legal frameworks. An example is the United Nations Convention on International Bills of Exchange and International Promissory Notes from 1988. Denmark complies with international law, but has been significantly affected by the introduction of the Eurozone and the European Central Bank's (ECB) attempt to harmonize the payment infrastructure (Kokkola, 2010). In particular, the Single Euro Payments Area (SEPA) affects both intrabank processing system and interbank transfer systems. SEPA is an integration project, in which the European Commission aims to improve the efficiency of cross-border payments and create unified payment market in Europe. SEPA is threatening the Danish payment infrastructure by forcing it to get in synch with the rest of Europe. However, Denmark has been able to avoid implement some aspects of the Eurozone treaty to protect the Danish debit card system.

Governmental agencies, including the Danish National Bank and the ECB, monitor and control the payments system. Private firms, such as credit card clearinghouses and banks, set up the rules and standards for payments, such as NETS and the banks. Standards govern the authorization, clearing, settlement, and the technologies used in payments (Kokkola 2010). For instance, SO 4217 is the International Standard for currency codes, ISO 13491-2:2005 specifies secure cryptographic devices in the financial services environment, and the future standard ISO 12812 is intended to address security and data protection, mobile person-to-person payments, mobile person-to-business payments, and requirements for mobile banking applications. 
This is the pre-edited version of "Hedman, J., and Henningsson, S. (2015) "The new normal: Market cooperation in the mp7 bile payments ecosystem”. Electronic Commerce Research and Applications, 14, 5, 305-318”.

Technology infrastructure operators maintain the underlying network and provide the systems capabilities that process payments, for instance, the Society for Worldwide Interbank Financial Telecommunication (SWIFT), the banks, NETS, and ECB. ${ }^{5}$ For instance, the National Bank maintains the national interbank transfer system, Kronos, and ECB runs TARGET 2 that processes payment transactions between banks in Europe and central banks across Europe. There are also hardware manufactures of mobile phones, point-of-sale (POS) terminals, card terminals, computers, and automatic teller machines (ATM) that provide end-user interfaces to the payment system (Kokkola 2010

The evolving payment infrastructure. The introduction of the Eurozone and SEPA has drastically changed the payments landscape over the last decade (Garcia-Swartz et al., 2006). The main current development in the payment market is the replacement of the physical and manual payment infrastructures with an open digital payment infrastructure. The infrastructure is defined as a multilateral system among participating institutions, including the operator of the system, used for the purposes of clearing, settling, or recording payments, securities, derivatives, or other financial transactions (CPSS, 2013). This infrastructure is in part based on mobile technologies (McKinsey, 2014a; Sveriges-Riksbank, 2013; WorldPaymentReport, 2014). This process started with payment cards and continued with Internet and mobile banks. The digitization of payments and the convergence with mobile technologies has been changing the market.

Banks all over the world have recognized the new state of the market. There is not only competition among the stakeholders. Denmark is a very small market with 5-plus million inhabitants, so they also are trying to collaborate. This goes both for the banks and the operators. The ECB has been pushing for collaboration as well, through efforts such as SEPA. However, when the banks or the telecom operators try to collaborate, the European Competition Agency sues them for misusing their market position.

\footnotetext{
${ }^{5}$ SWIFT was founded in Brussels in 1973 and provides a network that enables financial institutions worldwide to send and receive information about payment and other kinds of transactions. SWIFT offers software and services to financial institutions, much of it for use on the SWIFT network, and ISO 9362 bank identifier codes (BICs). The SWIFT network links more than 9,000 financial institutions in 209 countries that exchanges on average $15+$ million messages per day. SWIFT has become the industry standard for syntax in financial messages.
} 
This is the pre-edited version of "Hedman, J., and Henningsson, S. (2015) "The new normal: Market cooperation in the mp8 bile payments ecosystem". Electronic Commerce Research and Applications, 14, 5, 305-318".

For centuries the evolution of payments was slow and strictly controlled. Now, partly due to the convergence with mobile technologies, payments have become one of society's most innovative and dynamic sectors. We next focus on three such innovations: iZettle and its mobile payment card dongle, SMS payments, and the PayPal ecosystem.

\subsection{The Micro-Level of Cooperation: iZettle}

Starting at the micro level, the payment ecosystem is experiencing the introduction of new technological innovations, including smartphone payment card dongles. This technology competes with card terminals and electronic funds transfer at point-of-sale (EFTPOS), which have existed since the mid-1980s. Traditionally payment card clearinghouses, such as NETS, offer card terminals to merchants involving a contractual agreement for a monthly fee and a percentage of the transaction volume. They defend their market position by exploiting the near-monopoly position of DanKort. Furthermore, they are the only ones who are allowed by law to process DanKort transactions, and they have invested heavily in the related payment infrastructure to create cost-effective payment services at scale. The merchant gives the payer a terminal, provided by NETS, so their customers can swipe their cards for their transactions. The EFTPOS establishes a link to the payment card clearinghouse, which checks whether the card is valid and if there are available funds. Then the payer approves the transaction through a pin code. ${ }^{6}$ There were about 220,000 card terminals that managed over one billion card transactions in Denmark in 2013.

Over the past few years a contender to EFTPOS has emerged from start-ups, including companies such as Square (www.squareup.com) from USA and iZettle from Sweden (www.izettle.com) (Nationalbank, 2013). iZettle entered the Danish market in 2011 and offers smartphones owners to private and corporate customers through the use of a dongle, which converts the smartphone into an EFTPOS terminal. iZettle is registered as a payment services provider, not as a financial institution. Consequently, iZettle does not work under the same regulatory jurisdiction as a bank has to. iZettle has been applying a battering- ram strategy, involving technology that is compatible with

\footnotetext{
${ }^{6}$ Note that there are differences in the flow and the involved stakeholders for debit, credit and charge cards. Pin codes are well established in Denmark as authorizations mechanism, although the U.S. still uses signatures. Pin code is required by law for transactions above 25 Euro in Denmark.
} 
This is the pre-edited version of "Hedman, J., and Henningsson, S. (2015) "The new normal: Market cooperation in the mp9 bile payments ecosystem". Electronic Commerce Research and Applications, 14, 5, 305-318".

smartphones, by offering functionality that is similar to traditional EFTPOS, but with low fixed costs for transactions involving small businesses and consumers. It charges $2.75 \%$ of the cash value of each transaction. The offering has disrupted the marketplace by providing functionality to new market segments. In addition, for small merchants, iZettle has offered a small point-of-sale (POS) system.

NETS and Point do not currently provide this kind of service to their customers.

The dongle is compatible with existing smartphone communication ports. It uses the same installation procedure as for any software on a smartphone, such as the App Store or Google Play. iZettle utilized existing standards and a harmonized payment infrastructure when it launched a battering-ram strategy against NETS. The start-up has been exploiting the diffusion and capabilities of smartphones. However, this requires some collaboration and a partnership with Apple via its App Store and with Google via Google Play to deploy the applications to the smartphone. iZettle also has collaborated with MasterCard and VISA so it can accept these cards. The company also has collaborated with payment clearinghouses to verify the cards and transactions. For DanKort transactions, however, they actually use NETS' clearing functionality. In response, NETS launched MobilePenge - a person-toperson account payment transfer service that uses SMS functionality - with a large $7 \%$ transaction fee. NETS drew upon its existing network of banks and its control of NEM-Konto to increase the barriers of entry for this market.

\subsection{The Meso-Level of Cooperation: SMS Payments}

At the meso-level, there are mobile operators who provide SMS payment services. This type of payment is based on text messaging services in mobile communication systems. The SMS standard is part of the Global System for Mobile (GSM) Communications series of standards. The problem that SMSs solved was to send notifications to and from mobile phones, for example, to inform users of voice mail messages that have arrived. Nokia was the first phone manufacturer to implement the standard back in 1993. Since, then the use of SMS has exploded in volume. In 2010, for example, 6.1 trillion SMSs were sent, and their roles have changed from notifications to a tool for personal communication, accessing digital content, and making payments. 
This is the pre-edited version of "Hedman, J., and Henningsson, S. (2015) "The new normal: Market cooperation in the mळ0 bile payments ecosystem”. Electronic Commerce Research and Applications, 14, 5, 305-318”.

The Finnish mobile operator, Saunalahti, which is now part of the Elisa Group, introduced SMS payments in 1998, when they offered the world's first downloadable ring tones. Today, it is used for online payments, mobile application stores, bus tickets, and parking tickets. SMS payments use premium-rate telephone numbers for which prices are higher than normal. These SMS numbers are usually allocated by the national telephone numbering plan in such a way that they are easily distinguished from other numbers - for example, with four digits in Denmark. The provider of SMS payments uses either the telecom operators, such TDC, TeliaSonera, or 3, directly or through a payment gateway provider, such as Unwire. The mobile operator bills the charges for premium SMS services to the customers. Unlike a normal SMS, a part of the charges is paid to the service or content provider. The payout to the service provider varies between SMS number and operator, but up to $45 \%$ of the price is kept by the operator. SMS payments utilized a disruptive technology at that time to launch a service that was compatible with existing technologies, including the SMS standard, premium-rate telephone numbers, and the existing billing system of the operators.

SMS payments compete with banks and their payment cards in physical and online transactions as well as with cash payments. They are based on the collaboration between mobile operators and content providers or service vendors. This is an example of how industries can enter a new market and compete with business clusters. The existing ecosystem has not come up with a direct competing technology. But they are defending their market positions through lobbying and making large investment in creating common IT platforms. Kasper Sylvester Olsen from Dansk Bank explains:

"We had a new IT strategy saying we are a bank in multiple countries, ... we have one IT platform, then we have one product which is the same in Finland and Sweden and Denmark, and again we are just utilizing our IT platform and just have one to fit all countries."

Furthermore, the banks are responding with apps that could replace SMS payments. Olsen said:

"We have the remote mobile payments which is basically where you surf around the internet on the mobile and you pay by the credit card for instance, but it could also be using the app making payments that way and also pay by SMS."

SMS payments have some limitations. For instance, the law limits SMS payments to be no more than 30 Euro. Furthermore, SMS payments actually solve a bank issue, by reducing the use of coins in vending and parking machines. This may explain why the banks are willing to let the changes occur. 
This is the pre-edited version of "Hedman, J., and Henningsson, S. (2015) "The new normal: Market cooperation in the mळ1 bile payments ecosystem". Electronic Commerce Research and Applications, 14, 5, 305-318".

\subsection{The Macro-Level of Cooperation: PayPal}

PayPal may be a possible disruptor of the established payment ecosystem. PayPal was founded in 1998 and has over 120 million active accounts. It accepts payments in 25 currencies, including the Danish krone. PayPal is also registered as a bank in Luxembourg. It provides basic bank services, such as setting up accounts for individuals and merchants. It is possible to make PayPal payments and financial transactions through various web interfaces, mobile interfaces, and email. The growth and expansion of PayPal is based on a three-phase strategy, according to eBay's former CEO, Meg Whitman:

"First, PayPal focused on expanding its service among eBay users in the U.S. Second, we began expanding PayPal to eBay's international sites. And third, we started to build PayPal's business off eBay."

An example of this kind of expansion strategy was put into play by PayPal, which has been providing an application programming interface (API) for third-party software developers. This is a build-and-defend strategy. PayPal is expanding its payment functionality from within the eBay ecosystem to become a global provider of payment services. This is still in process, even though PayPal and eBay are separate legal entities today.

The functionality found in PayPal is represents a technology regime. Similar to payment dongles and SMS payments, PayPal utilizes existing technology components and systems. It never came up with its own disruptive technologies, but instead PayPal built upon existing technology standards. However, PayPal adapted its services to different platforms, from eBay to e-commerce sites to mobile ecosystems, such as iPhone and Android. It grew organically and has slowly begun to attack the payment ecosystem. PayPal's collaboration and partnering with different stakeholders in the payment market has involved the major payment cards companies, such as VISA and MasterCard. And, in Denmark, PayPal collaborates with a foreign small bank, Skandinaviska Enskilda Banken (SEB), which allows PayPal users to transfer money from the banking system to their PayPal accounts. Furthermore, they are collaborating with e-commerce firms, by having an API to enable integration between PayPal and e-commerce sites. The current business models of PayPal have components that may be able to challenge the dominance of the existing payment ecosystem. 
This is the pre-edited version of "Hedman, J., and Henningsson, S. (2015) "The new normal: Market cooperation in the mळ2 bile payments ecosystem". Electronic Commerce Research and Applications, 14, 5, 305-318".

The reaction towards this potential enemy has been indirect to date. The established payment ecosystem continues to invest in existing infrastructure to provide users with better services than PayPal. For instance, the launch of mobile banking services by Dansk Bank and Nordea have been huge successes. Dansk Bank used Facebook to involve its customers in the development of their mobile banking services, for example. A key resource for the banks in this battle is their local presence and the trust they have built with their customer bases.

\subsection{Summary and Discussion of Cases}

Table 4 summarizes the findings focusing on the market cooperation strategies. We have presented three cases of payment market entrants. They all challenge the existing payment stakeholders in different ways, but they also share some commonalities. The battering-ram strategy utilized by PayPal, mobile operators, and the dongle businesses involve uses of technology to gain market positions. PayPal use API's to offer Internet payments service on e-commerce and m-commerce sites. Mobile operators on the other hand launched a disruptive technology and thereby surpassed traditional payments system and turned mobile operators into payment intermediary. The dongle business converts a smartphone into a card terminal by adding a dongle. This solution depends on collaboration with MasterCard and VISA. The three contenders share one thing as well. They all a linkage to the traditional payment system either through payment cards or payment services provided by the banks.

\section{INSERT TABLE 4 ABOUT HERE}

The existing traditional stakeholders try to built-and-defend their current market position by using existing technology infrastructure as a barriers of entry. The banks seek to prevent entry by PayPal by denying access to payment infrastructure. In particular, they protect the bank accounts. When it comes to the SMS payment service, the banks increases its investments in the traditional payment infrastructure, such as Internet banks, mobile banks, and extends the diffusion of card readers. Thereby they create higher barriers of entry.

Interestingly the stakeholders in the cases frequently collaborate in the their use of battering-ram and built-and-defend strategies. In particular the global payment card schemas provided by VISA and 
This is the pre-edited version of "Hedman, J., and Henningsson, S. (2015) "The new normal: Market cooperation in the m§3 bile payments ecosystem". Electronic Commerce Research and Applications, 14, 5, 305-318".

MasterCard are used both by PayPal and the dongle business and the banks, which is linked to national debit card schema. The operators collaborate with the banks, since they use the banks for collecting money for the SMS payment service. Thus, there is a win-win situation for all stakeholders in this battle.

\section{DISCUSSION}

We next discuss the validity and limitations of the proposed framework. Drawing on Glaser (1978), we will evaluate its validity in terms of integration of the framework, its relative explanatory power, and its theoretical and practical relevance.

\subsection{Framework Integration}

The MPMC framework, outlined in figure 1, depicts market cooperation in mobile payment ecosystems. The horizontal dimension shows the co-opetive relations between existing businesses with their installed bases of technology, and new entrants with technological innovations that are trying to enter the market. The existing businesses, clusters or ecosystems use a build-and-defend strategy to fight off newcomers. They use existing technologies, such as NETS payment card clearing systems and shared technologies to create barriers to entry. Market entrants employ internet and mobile technology as a battering-ram to gain access and profitable positions in the market.

The vertical dimension suggests that this battle occurs on three levels: the micro, meso, and macro-levels. At the micro-level, individual business units collaborate and compete with strategies based on proprietary technologies, e.g. iZettel has their dongle that competes with traditional card readers which are proprietary technology owned by NETS. At the meso-level, formal and informal strategic networks and alliances are formed as a result of stakeholders joining forces in clusters to compete with other clusters of stakeholders using strategies based on shared technologies, e.g. the national debit card system competes with the SMS payment service fro mobile operators. On the macro-level, the ecosystem of interdependent stakeholders as a whole competes with other ecosystems through strategies based on technology regimes. Here we find how PayPal challenge the entire banking system with its payment system and associated services, but meanwhile used existing componets, such as 
This is the pre-edited version of "Hedman, J., and Henningsson, S. (2015) "The new normal: Market cooperation in the mळ4 bile payments ecosystem". Electronic Commerce Research and Applications, 14, 5, 305-318".

payment cards, in collaboration with the financial market. The vertical dimension also shows how collaboration occurs between the levels through system, cluster, regime, and ecosystem collaboration.

Six competitive battles take place within the horizontal and vertical dimensions of the mobile ecosystem, including technology, business unit, systemic, cluster, regime, and ecosystem competition. For technology, systemic, and regime competition, the key questions involve market adoption and acceptance. Managing time-to-market is one way of achieving this. For business units, cluster, and ecosystem-based competition, the main issue is how to reach a favorable market position in terms of profit or market share.

\subsection{Explanatory Power}

The MPMC framework provides a means for explaining how technology-based market cooperation strategies are enacted in payment ecosystems. Previous research related to technology-based market coordination strategies has examined standards wars and system-based competition. An example is Shapiro and Varian (2013). However, these approaches are focused on specific competitive initiatives, while an ecosystem approach to market co-opetition captures the many simultaneously ongoing competition and collaboration strategies that shape the ecosystem marketplace. Similar, research on mobile payment evolution, such as Ballon et al. (2007); Carton et al. (2012); Chae and Hedman (2015); Ondrus and Pigneur (2006), tend focus on the technology and thereby ignoring the competitive landscape they exist within. Furthermore, they rarely take a holistic approach looking at the interaction and interdependency between stakeholders. The MPMC framework addresses shortcomings in in technology-based market coordination and mobile payment research by integrates several theoretical perspectives, as we noted earlier. The explanatory power of the ecosystem approach lies in its holistic explanation of technology-based market cooperation. This view stresses that technology evolution cannot be studied in isolation, but has to be seen in light of how evolution works in a context with many interdependencies (see e.g. Adomavicius et al., 2007; McKinsey, 2014b).

As an explanatory model, the MPMC framework sheds light on why existing stakeholders in the payment ecosystem think of the current state of affairs as the "new normal." Based on the framework, we concluded that the digitization of the ecosystem's services has radically changed the way business 
This is the pre-edited version of "Hedman, J., and Henningsson, S. (2015) "The new normal: Market cooperation in the mळ5 bile payments ecosystem”. Electronic Commerce Research and Applications, 14, 5, 305-318”.

strategy has played out. The positioning of technological innovations has become an integral part of the battle for market position. In these battles, the competitors can use technology either in defensive build-and-defend strategies to protect market position or in offensive battering-ram strategy for ecosystem entry or position improvement. The successful use of these technology-based strategies can lead to Ricardian rents, based on operational efficiency advantages that are created due to power over suppliers and positioning for monopoly-power. It also can support the earning of Bainian rents, resulting from developing resistance to price competition. These things contribute to profitability in mobile ecosystems.

The MPMC framework also enables an analyst to construct an explanation for why some entrants have been more successful than others in entering the ecosystem penetration. The explanation is that entry success is not only contingent on the entrant's ability to develop and use a technological battering-ram, but also on the existing ecosystem stakeholders' ability to build a technology-based line of defense. Where this happens, for example, in the joint development of Mobil-Penge, ecosystem entry becomes more problematic. Furthermore, our analysis shows that the success of new entrants lies in their ability to collaborate in the Danish market in order to get access to the underlying infrastructure.

Finally, the MPMC framework explains why stakeholders such as the ECB are seeking to inhibit some collaborative technology initiatives, while forcing standardization in other areas, such as with SEPA payments. Part of the explanation lies in considering technology initiatives based on their impact on market cooperation and barriers to entry. Strong market positions defended by technology lowers price rivalry at the expense of customers. Consequently, the ECB has blocked such initiatives, while the adoption of open standards is expected to benefit consumers by increasing price rivalry.

\subsection{Theoretical and Practical Relevance}

This article adds to the literature on technology ecosystem (Adomavicius et al., 2007; Basole and Karla, 2011; Moore, 1996; Selander et al., 2013), in general, and m-payments ecosystem (Ballon et al., 2007; Ondrus and Lyytinen, 2011), in particular, by theorizing about how technology-related characteristics influence stakeholder cooperation strategies. The MPMC framework contributes an explanation of how beneficial market positions have been and can be achieved in the ecosystem. As 
This is the pre-edited version of "Hedman, J., and Henningsson, S. (2015) "The new normal: Market cooperation in the m凤6 bile payments ecosystem”. Electronic Commerce Research and Applications, 14, 5, 305-318”.

more and more industries adopt mobile technologies and are increasingly becoming part of ecosystems, the relevance of this knowledge will grow. We believe that the MPMC framework can be used to understand competitive battles in the music, gaming and entertainment industries. However, the degree of collaboration that we found in payment eco-system might vary a lot.

The MPMC framework also contributes to the literature on how IT relates to business-level strategy. Drawing on the Makadok's $(2006,2011)$ categorization of strategic management theory, Drnevich and Croson (2013) explored whether and how IT investments contribute to the four valuecreating mechanisms. Their conclusion is that there are possibilities for IT-based value creation in all four profit mechanisms (collusion, governance, competence, and flexibility), but there is a lack of theory related to the link between technology investments and the mechanisms that generate value. In addition, Drnevich and Croson (2013) analyze the role of IT in market cooperation strategy, but they do so for non-digital markets in which technology aids in producing the services and products, but is not part of them itself. IT is a central part of the offerings in digital markets, such as payments, music, games, etc., that are characterized by two-sided markets

From a practical point of view, this article contributes towards understanding and exploiting the dynamics of the mobile payments industry. For the growing number of industries that offer mobile technologies, exploiting these specific characteristics is a key challenge for firm success. Existing stakeholders can take two positions in the blocking of new entrants: to face them on the micro-level or the meso-level. Facing the new stakeholders on a micro-level leads to the acceptance of rival competitive systems. This can be motivated by the fact that the new entrants are not direct competitors. Facing new entrants on the meso-level yields two options: systemic competition or inclusion in clusters. An example of the first is Danske Bank's collaboration with an external provider for their iPhone application. An example of the latter is the clustered competition of rival systems for SMS payments. Traditional stakeholders, such as the banks, are forced to collaborate to defend against a rival system that indirectly threatens their existing business. As summarized by McKinsey (2014a):

"The challenge for banks is to shift from their traditional heavy reliance on siloed, proprietary data, to a more open approach that encompasses a broader view of customers."

Similar ideas are expressed in the World Payment Report: 
This is the pre-edited version of "Hedman, J., and Henningsson, S. (2015) "The new normal: Market cooperation in the mळ7 bile payments ecosystem". Electronic Commerce Research and Applications, 14, 5, 305-318".

"The role of banks in the payments industry may change radically. In several major countries, banks may no longer be the only party at the center of payments governance, as regulators encourage non-banks and retailers to play a bigger role" (WorldPaymentReport, 2014, p. 52).

Regardless of the level of encounter, market entry is blocked by increasing level of capital investment in technology required to enter, or by restraining access to specific technology that complements the entrants' services offerings. For new entrants, a decision has to be made on the level of entry, and it is two-sided. On the one hand, it is based on the new entrant's capacity to create a disruptive technology that can be used for a battering- ram strategy. On the other hand, the decision is based on the existing stakeholders' ability to create technology-based barriers to entry. At the different levels in the ecosystem, this ability can be severely constrained by legislation or decisions involving regulatory bodies. Thus this makes collaboration with existing stakeholders crucial for the entrants.

For regulatory bodies that have an interest in governing the ecosystem, awareness of how technology is used in market cooperation is essential. The cases showed that it is necessary to carefully assess technology adoption and collaboration to investigate their impacts on market cooperation. However, based on the experience of Danish banks, this assessment is frequently misguided, as the ECB has stopped some initiatives that actually would benefit the consumer. As a result, the banks have not created barriers to entry or fortified their current market positions. The MPMC framework can assist regulatory bodies in assessing the effects market dynamics by technology initiatives.

\subsection{Limitations}

The most important limitation of the research in this article is that it only addresses one of the four mechanisms for business-level strategy (Makadok 2003, 2011) in the explanation to how technology drives changes in technology-intensive industries. Subsequent research should examine the three remaining categories of business-level strategy: governance, capabilities, and flexibility. Based on our studies of the m-payments ecosystem, the inclusion of mobile technology has important implications for the other profit-generating mechanisms. Compatibility dependencies between ecosystem stakeholders are likely to present additional governance challenges. Existing stakeholders, such as the banks and payment transaction providers, clearly have to develop new capabilities to compete in the hypercompetitive payment ecosystem. And in these turbulent environments, competitors that can de- 
This is the pre-edited version of "Hedman, J., and Henningsson, S. (2015) "The new normal: Market cooperation in the mळ8 bile payments ecosystem”. Electronic Commerce Research and Applications, 14, 5, 305-318”.

ploy information technology enabling flexibility and constant organizational innovation are likely to be successful contenders over time. Another limitation of the framework is the number of cases used to validate it. In future research, we encourage researchers to include more cases to validate each level of the analysis. In addition, it would be fruitful to challenge and extend to the market cooperation framework to other two-sided markets in digital industries, such as music, games, books, travel, etc.

\section{CONCLUSION}

Payment innovations are changing the payment market, as we know it. Stakeholders are applying technologies in new ways or inventing new technologies. One of the key technologies in this innovation war is the mobile phone. Bankers refer to this as the "new normal." To make sense of the new competitive landscape, we developed a mobile payment market cooperation (MPMC) framework. The framework is grounded in market cooperation theories (Drnevich and Croson, 2013; Makadok, 2003, 2011), technology ecosystem theory (Adomavicius et al., 2007) and business ecosystems theory

(Basole 2009, Selander et al. 2013) and is validated with case studies from Denmark.

The framework explains competition and collaboration in payments ecosystems. Our ecosystem analysis fosters a broad and comprehensive thinking beyond isolated technologies or specific stakeholders. The MPMC framework is divided into three levels: micro, meso and macro. Co-opetitive relations exist on all three levels, and so do classes of compatible and incompatible technologies. Consequently, technology-based market cooperation strategy in mobile payment ecosystems can be understood as a three-leveled balance between defensive and offensive technology-based strategies. Existing stakeholders trying to protect their market positions can apply the build-and-defend defensive strategy. If they are successful, this will lead to the creation of Ricardian rents from operational efficiency advantages traceable to the firm's power and position over its suppliers and the development of monopoly-power. The newcomers, in contrast, seek to gain Bainian rents, resulting from being able to resist price competition in the marketplace by applying the offensive battering-ram strategy. 
This is the pre-edited version of "Hedman, J., and Henningsson, S. (2015) "The new normal: Market cooperation in the mळ9 bile payments ecosystem". Electronic Commerce Research and Applications, 14, 5, 305-318".

\section{APPENDIX 1. DATA SOURCES FOR THE CASE NARRATIVES}

\section{Domains AND Data Sources}

\section{- Payment Ecosystem Background}

Amundsen and Kalsone (2009), Bakkegaard (2009), Carlsen and Riishøj (2009), Kokkola (2010), Rørdam (2010), Danmarks Nationalbank (1999-2012, 2005, 2011), NETS (2010-2012), Finansrådet (2011a, 2011b), Sveriges Riksbank (2013)

\section{- Case 1: iZettle}

www.izettle.com www.bbc.co.uk/news/technology-20226894

www.computerworld.com/s/article/9233567/Visa_startup_iZettle_settle_mobile_payments_issue

www.techcrunch.com/2012/11/13/europes-square-izettle-exits-beta-in-nordics-and-finds-workaround-for-visa-acceptance/ www.techcrunch.com/2013/02/20/izettle-launches-launches-wireless-chip-pin-device-starts-taking-visa-and-partners-with-santander/ www.ft.com/intl/cms/s/0/680a518c-28d0-11e2-b92c-00144feabdc0.html

www.dn.se/blogg/teknikbloggen/2012/11/13/nu-tar-izettle-visa-i-norge-danmark-och-finland-igen

www.zdnet.com/izettle-adds-new-loyalty-analytics-features-as-it-squares-up-to-square-7000013527/

thenextweb.com/insider/2012/12/04/izettle-partners-with-nordea-bank-to-give-its-card-readers-away-free-to-smes-in-sweden/

\section{- Case 2: SMS Payments}

Bakkegaard (2009)

www.mobilepronto.org; www.unwire.dk; www.nokia.com; www.gsmworld.com

www.fi.se/upload/43 Utredningar/40 Skrivelser/2013/sms-biljett FragorSvar 130131.pdf

www.swedishbankers.se/web/bf.nsf/(\$All)/2AB5E599EEE4E790C125774A004BAFD7?OpenDocument

\section{- Case 3: PayPal}

www.paypal.com

eBay annual report 2000-2011

Edelman and Hagiu (2011),

Eisenmann and Barley (2007)

www.ft.com $/$ intl $/ \mathrm{cms} / \mathrm{s}$

www.nytimes.com/2010/11/29/technology/29paypal.html? $\mathrm{r}=0$

bits.blogs.nytimes.com/2011/09/15/paypal-prepares-for-a-move-offline

\section{- Cooperation Workshops}

GetFit: Hvordan laves gode udbud og kravspecifikationer for procesorienterede digitaliseringsløsninger GetFit: Mobilbetalinger

GetFit: Produkt og Service Innovation dagen 2012

GetFit: Munich and Denmark: Finance and IT Across Borders

GetFit: European Finance Associations (EFA) Conference

GetFit: Future of Finance: Business

\section{- Interviews}

Kasper Sylvest Olsen, Dansk Bank, Senior Financial Infrastructure Manager

Claus Bunkenberg, Dansk Bank, Head of multi-channel management

Jørgen Andersen, Dansk Bank, Enterprise Architect

Tony Jensen, Cellpoint Mobile, CEO

Per Harald Strøm, NETS, Senior Vice Presedent

\section{Date, Time}

6 Feb 2013, 08:50-13:45

29 Jan 2013, 16:00-18:00

29 Nov 2012, 08:30-15:30

15-16 Nov 2012

15 Aug 2012, 08:45-17:00 14 May 2012, 16:00-18:00

\section{Date}

2011-09-30, 2012-03-27

2012-03-26

2012-05-15

2012-03-12, 2013-03-01

2012-11-15

\section{- Related Literature}

Amundsen, E., Kalsone, D. (2009). E-Payment products and value-added services: moving towards an innovative European internal market. Danmarks Nationalbank, Copenhagen, Denmark.

Bakkegaard, J. (2009). Mobilbetalinger. Danmarks Nationalbank, Copenhagen, Denmark.

Carlsen, M., Riishøj, J.D. (2009). Brug af kontanter i Danmark. Danmarks-Nationalbank, Copenhagen, Denmark.

Danmarks-Nationalbank. (1999-2012). Beretning og regnskap. Danmarks-Nationalbank, Copenhagen, Denmark.

Danmarks-Nationalbank. (2005). Betalningsformidling i Danmark. Danmarks Nationalbank, Copenhagen, Denmark.

Danmarks-Nationalbank. (2011). Costs of payments in Denmark. Danmarks-Nationalbank, Copenhagen, Denmark.

eBay. (2000-2012). Annual reports. San Jose, CA.

Edelman, B., Hagui, A. (2011). Consumer payments systems: United States. Case 9-909-006, Harvard Business School, Boston, MA. Eisenmann, T., Barley, L. (2007). PayPal merchant service. Case 9-806-188, Harvard Business School, Boston, MA.

Finansrådet. (2011a). Bankerne: kort fortalt. Finansrådet, Copenhagen, Denmark.

Finansrådet. (2011b). Fremtidig finansiel regulering. Finansrådet, Copenhagen.

Kokkola, T. (Ed.). (2010). The payment system. European Central Bank, Frankfurt am Main, Germany

NETS. (2010-2012). Annual report. Ballerup, Denmark.

Rørdam, K. (2010). Essays in payment systems and financial stability. Copenhagen, Denmark.

Sveriges Riksbank. (2013). The Swedish retail payment market. Riksbank Studies, Stockholm, Sweden, June. 
This is the pre-edited version of "Hedman, J., and Henningsson, S. (2015) "The new normal: Market cooperation in the mछ0 bile payments ecosystem”. Electronic Commerce Research and Applications, 14, 5, 305-318”.

\section{REFERENCES}

Adomavicius, G., Bockstedt, J.C., Gupta, A., Kauffman, R.J., 2007. Technology roles and paths of influence in an ecosystem model of technology evolution. Information Technology and Management $8,185-202$.

Bain, J.S., 1956. Barriers to new competition: their character and consequences in manufacturing industries. Harvard University Press Cambridge, MA.

Bakos, Y., Brynjolfsson, E., 1999. Bundling information goods: Pricing, profits, and efficiency. Management Science 45, 1613-1630.

Ballon, P., Van Bossuyt, M., Van Hove, L., 2007. Mobile payment models and their implications for NextGen MSPs. info 9, 31-43.

Basole, R.C., 2009. Visualization of interfirm relations in a converging mobile ecosystem. Journal of Information Technology 24, 144-159.

Basole, R.C., Karla, J., 2011. On the evolution of mobile platform ecosystem structure and strategy.

Business \& Information Systems Engineering 3, 313-322.

Brandenburger, A.M., Nalebuff, B.J., 2011. Co-opetition. Random House LLC.

Carton, F., Hedman, J., Damsgaard, J., Tan, K.-T., McCarthy, J., 2012. Framework for Mobile

Payments Integration. Electronic Journal of Information Systems Evaluation 15, 14-25.

Chae, J.S.U., Hedman, J., 2015. Business Models for NFC based mobile payments. Journal of Business Models 3, 29-48.

Christensen, C.M., Overdorf, M., 2000. Meeting the challenge of disruptive change. harvard business review 78, 66-77.

CPSS, 2013. Statistics on payment, clearing and settlement systems in the CPSS countries: Figures for 2012. Bank for International Settlements.

Drnevich, P.L., Croson, D.C., 2013. Information Technology and Business-Level Strategy: Toward an Integrated Theoretical Perspective. MIS Quarterly 37, 483-509.

Eisenhardt, K.M., 1989. Building Theory from Case Study Research. Academy of Management Review 14, 532-550.

Evans, D.S., Hagiu, A., Schmalensee, R., 2006. Invisible engines: How software platforms drive innovation and transform industries. The MIT Press, Boston.

Ferguson, N., 2009. The ascent of money: a financial history of the world. Penguin Books, London ; New York, N.Y.

Garcia-Swartz, D., Hahn, R., Layne-Farrar, A., 2006. The move toward a cashless society: A closer look at payment instrument economics. Review of Network Economics 5, 175-197.

Gartner, 2014. Hype Cycle for Payment Innovations, 2014, in: Uzureau, C. (Ed.). Gartner

Gawer, A., Henderson, R., 2007. Platform owner entry and innovation in complementary markets:

Evidence from Intel. Journal of Economics \& Management Strategy 16, 1-34.

Ghazawneh, A., Henfridsson, O., 2012. Balancing platform control and external contribution in thirdparty development: The boundary resources model. Information Systems Journal 23, 173-192. Glaser, B.G., 1978. Theoretical sensitivity: Advances in the methodology of grounded theory. Sociology Pr.

Henderson, R.M., Clark, K.B., 1990. Architectural innovation: The reconfiguration of existing product technologies and the failure of established firms. Administrative science quarterly 35, 9-30. Henningsson, S., Henriksen, H.Z., 2011. Inscription of behaviour and flexible interpretation in Information Infrastructures: The case of European e-Customs. Journal of Strategic Information Systems 20, 355-372.

Iansiti, M., Khanna, T., 1995. Technological evolution, system architecture and the obsolescence of firm capabilities. Industrial and Corporate Change 4, 333-361.

Iansiti, M., Levien, R., 2004. The keystone advantage: What the new dynamics of business ecosystems mean for strategy, innovation, and sustainability. Harvard Business Press, Boston. Katz, M.L., Shapiro, C., 1994. Systems competition and network effects. The Journal of Economic Perspectives 8, 93-115.

Kokkola, T., 2010. The payment system. European Central Bank, Frankfurt am Main. 
This is the pre-edited version of "Hedman, J., and Henningsson, S. (2015) "The new normal: Market cooperation in the m 81 bile payments ecosystem”. Electronic Commerce Research and Applications, 14, 5, 305-318”.

Lee, C.H., Venkatraman, N., Tanriverdi, H., Iyer, B., 2010. Complementarity-based hypercompetition in the software industry: Theory and empirical test, 1990-2002. Strategic Management Journal 31, 1431-1456.

Makadok, R., 2003. Doing the right thing and knowing the right thing to do: Why the whole is greater than the sum of the parts Strategic Management Journal 24, 1043-1055.

Makadok, R., 2006. Four theories of persistent profit under competition, and their interaction effects. Working paper. Goizueta Business School, Emory University.

Makadok, R., 2011. Invited editorial: The four theories of profit and their joint effects. Journal of Management 37, 1316-1334.

March, J.G., Simon, H.A., 1958. Organizations. John Wiley and Sons, New York.

May, R.M., Levin, S.A., Sugihara, G., 2008. Complex systems: Ecology for bankers. Nature 451, 893-895.

McKinsey, 2014a. Global Payments 2014: A Return to Sustaiable Growth Brings New Challenges. McKinsey, 2014b. The Road Back: McKinsey Global Banking Annual Review 2014, in: Dietz, M., Härle, P., Hyde, P., Kapoor, A., Lemerle, M., Nauck, F. (Eds.). McKinsey \& Company.

Messerschmitt, D.G., Szyperski, C., 2005. Software ecosystem: Understanding an indispensable technology and industry. MIT Press Books, Boston.

Milgrom, P., Roberts, J., 1990. The economics of modern manufacturing: Technology, strategy, and organization. The American Economic Review, 511-528.

Moore, J., 1996. The Death of Competition: Leadership and Strategy in the Age of Business

Ecosystems,. Harper Business, New York, NY.

Nalebuff, B.J., Brandenburger, A., Maulana, A., 1996. Co-opetition. HarperCollinsBusiness.

Nationalbank, D., 2013. RAPPORT OM NYE BETALINGSLØSNINGER.

Ondrus, J., Lyytinen, K., 2011. Mobile Payments Market: Towards Another Clash of the Titans?, The 10th International Conference on Mobile Business (ICMB), Como, Italy.

Ondrus, J., Pigneur, Y., 2006. Towards a holistic analysis of mobile payments: a multiple perspectives approach. Electronic Commerce Research and Applications 5, 246-257.

Pfeffer, J., Salancik, G.R.X., 2003. The external control of organizations: A resource dependence perspective. Stanford University Press.

Porter, M.E., 1985. Competitive advantage: Creating and sustaining superior performance. Free press, Boston.

Ricardo, D., 1817. On foreign trade. Principles of Political Economy and Taxation.

Rochet, J.C., Tirole, J., 2003. Platform competition in two-sided markets. Journal of the European Economic Association 1, 990-1029.

Sawy, O.A.E., 2003. The IS Core IX: The 3 Faces of IS identity: Connection, immersion, and fusion. Communications of the Association for Information Systems 12, 588-598.

Selander, L., Henfridsson, O., Svahn, F., 2010. Transforming ecosystem relationships in digital innovation, 31st International Conference on Information Systems, St. Louis.

Selander, L., Henfridsson, O., Svahn, F., 2013. Capability search and redeem across digital ecosystems. Journal of Information Technology 28, 183-197.

Shane, S., 2001. Technology regimes and new firm formation. Management science 47, 1173-1190. Shapiro, C., Varian, H.R., 1998. Versioning: The smart way to sell information. Harvard Business Review 107, 107-114.

Shapiro, C., Varian, H.R., 2013. Information rules: a strategic guide to the network economy. Harvard Business Press.

Stabell, C.B., Fjeldstad, Ø.D., 1998. Configuring value for competitive advantage: on chains, shops, and networks. Strategic Management Journal 19, 413-437.

Sveriges-Riksbank, 2013. The Swedish retail payment market. Riksbank Studies.

Tanriverdi, H., Lee, C.-H., 2008. Within-industry diversification and firm performance in the presence of network externalities: Evidence from the software industry. Academy of Management Journal 51, 381-397.

Tansley, A., 1935. The use and abuse of vegetational terms and concepts. Ecology 16, 284-307.

Walley, K., 2007. Coopetition: An introduction to the subject and an agenda for research.

International Studies of Management and Organization 37, 11-31. 
This is the pre-edited version of "Hedman, J., and Henningsson, S. (2015) "The new normal: Market cooperation in the m 82 bile payments ecosystem”. Electronic Commerce Research and Applications, 14, 5, 305-318”.

Weick, K.E., 1969. The social psychology of organizing. Addison-Wesley, Reading, MA.

WorldPaymentReport, 2014. World Payment Report 2014. Capgemini and The Royal Bank of Scotland.

Yin, R.K., 1984. Case Study Research: Design and Methods. SAGE, Thousand Oaks.

Yoo, Y., Lyytinen, K., Boland, R., 2008. Innovation in the Digital Era: Digitization and Four Classes of Innovation Networks.

Zammuto, R.F., Griffith, T.L., Majchrzak, A., Dougherty, D.J., Faraj, S., 2007. Information technology and the changing fabric of organization. Organization Science 18, 749-762. 
This is the pre-edited version of "Hedman, J., and Henningsson, S. (2015) "The new normal: Market cooperation in the m33 bile payments ecosystem". Electronic Commerce Research and Applications, 14, 5, 305-318".

Table 1. Technology-Based Market Cooperation Strategy in Mobile Ecosystems

\begin{tabular}{|l|l|l|}
\hline STRATEGIES & APPLICABLE FOR & STRATEGIC OPTIONS \\
\hline \multirow{2}{*}{ Build-and-defend } & $\begin{array}{l}\text { Existing stake- } \\
\text { holders }\end{array}$ & $\begin{array}{l}\text { Increase technology investment costs for taking part in ecosystem } \\
\text { Safeguard technology access }\end{array}$ \\
\hline \multirow{3}{*}{ Battering-ram } & $\begin{array}{l}\text { New entrants, } \\
\text { expanding exist- } \\
\text { ing stakeholders }\end{array}$ & $\begin{array}{l}\text { Compatible technology innovation } \\
\text { Semi-compatible technology innovation } \\
\text { Disruptive technology innovation }\end{array}$ \\
\hline
\end{tabular}

Table 2. Research Reliability and Validity Based on Yin (1984)

\begin{tabular}{|c|c|}
\hline RELIABILITY & DITY \\
\hline $\begin{array}{l}\text { - Case study protocols } \\
\circ \text { List of stakeholders } \\
\circ \text { Organization charts with potential informants } \\
\circ \text { Interview guide with areas of interest } \\
\circ \text { Strategy to allow for new information } \\
\circ \text { Strategies for different informant competences } \\
\circ \text { Risk areas with potential personal interests } \\
\text { - Case study database } \\
\circ \text { Audio recording, transcriptions } \\
\circ \text { Project documentation } \\
\circ \text { Field notes with potential alternatives } \\
\circ \text { Outcomes of reviews and informal discussions }\end{array}$ & $\begin{array}{l}\text { - Multiple sources of evidence } \\
\text { - } \text { See Appendix } 1 \\
\text { Establishing chain of evidence } \\
\circ \text { Extended case stories with use of quotes } \\
\circ \text { Key findings of knowledge and learning } \\
\text { mechanism linked to specific quotes } \\
\text { - Review of case drafts } \\
\circ \text { Draft case stories were shared with employees } \\
\text { of investigated organizations } \\
\circ \text { Feedback corrected minor misconceptions of } \\
\text { how processes unfolded, but supported our } \\
\text { conception of technology-based market coop- } \\
\text { eration strategy in the ecosystem. }\end{array}$ \\
\hline
\end{tabular}

Table 3. Key Stakeholders and Change Drivers in the Danish Payment Market

\begin{tabular}{|c|c|}
\hline STAKEHOLDERS & ROLES \\
\hline $\begin{array}{l}\text { - Danmarks Nationalbank, the Danish } \\
\text { Central Bank }\end{array}$ & $\begin{array}{l}\text { - Controls and monitors the payment system } \\
\text { - Provides interbank transfer system }\end{array}$ \\
\hline - $\quad$ Finansrådet (Bankers Association) & - Lobbying organization that aims to protect existing banks \\
\hline - Banks (Dansk Bank and Nordea) & - Provides accounts, payment instruments to payers and payees \\
\hline - $\quad$ NETS & $\begin{array}{l}\text { - } \text { Provides national debit card schema } \\
\text { - Acts as the clearing house for payment cards }\end{array}$ \\
\hline CHANGE DRIVERS & IMPACTS \\
\hline - Digitalization and mobile fusion & - Lowers barriers of entry for new competitors \\
\hline $\begin{array}{l}\text { - European Union and regulation, such as } \\
\text { SEPA }\end{array}$ & $\begin{array}{l}\text { - Forcing Denmark to open up its payment infrastructure and } \\
\text { harmonize payment fees with the rest of Europe }\end{array}$ \\
\hline
\end{tabular}

Table 4. Cooperation Strategies in the Payments Ecosystem

\begin{tabular}{|c|c|c|c|}
\hline \multirow{2}{*}{ LEVEL OF ANALYSIS } & \multirow{2}{*}{$\begin{array}{c}\text { STAKEHOLDERS IN } \\
\text { BATTLE }\end{array}$} & \multicolumn{2}{|c|}{ STRATEGY } \\
\hline & & Built-and-Defend & Battering-Ram \\
\hline $\begin{array}{l}\text { Macro: Business eco- } \\
\text { system versus technolo- } \\
\text { gy regime innovations }\end{array}$ & $\begin{array}{l}\text { Banks versus Pay- } \\
\text { Pal }\end{array}$ & $\begin{array}{l}\text { Ignoring new competitors and } \\
\text { safeguarding access to pay- } \\
\text { ment infrastructure }\end{array}$ & $\begin{array}{l}\text { Offer Internet payments service, using } \\
\text { semi-compatible technology through } \\
\text { payment cards for access payment in- } \\
\text { frastructure and provide APIs }\end{array}$ \\
\hline $\begin{array}{l}\text { Meso: Business clusters } \\
\text { versus shared technolo- } \\
\text { gy innovations }\end{array}$ & $\begin{array}{l}\text { Banks and their } \\
\text { traditional payment } \\
\text { instruments (cards } \\
\text { or cash) versus mo- } \\
\text { bile operators }\end{array}$ & $\begin{array}{l}\text { Investing in traditional pay- } \\
\text { ment infrastructure and } \\
\text { safeguarding technology } \\
\text { access }\end{array}$ & $\begin{array}{l}\text { Disruptive IT right from the start } \\
\text { SMS payments surpassed traditional } \\
\text { payments } \\
\text { Turned mobile operators into payment } \\
\text { intermediaries }\end{array}$ \\
\hline $\begin{array}{l}\text { Micro: Business units } \\
\text { versus component tech- } \\
\text { nology innovations }\end{array}$ & NETS versus iZettle & $\begin{array}{l}\text { Protecting, investing in exist- } \\
\text { ing technology infrastruc- } \\
\text { ture, including DanKort }\end{array}$ & $\begin{array}{l}\text { Converting a smartphone to a card } \\
\text { terminal by adding a dongle. Collab- } \\
\text { oration with MasterCard and VISA }\end{array}$ \\
\hline
\end{tabular}


This is the pre-edited version of "Hedman, J., and Henningsson, S. (2015) "The new normal: Market cooperation in the m84 bile payments ecosystem”. Electronic Commerce Research and Applications, 14, 5, 305-318”.

Figure 1. Mobile Payment Market Cooperation (MPMC) Framework

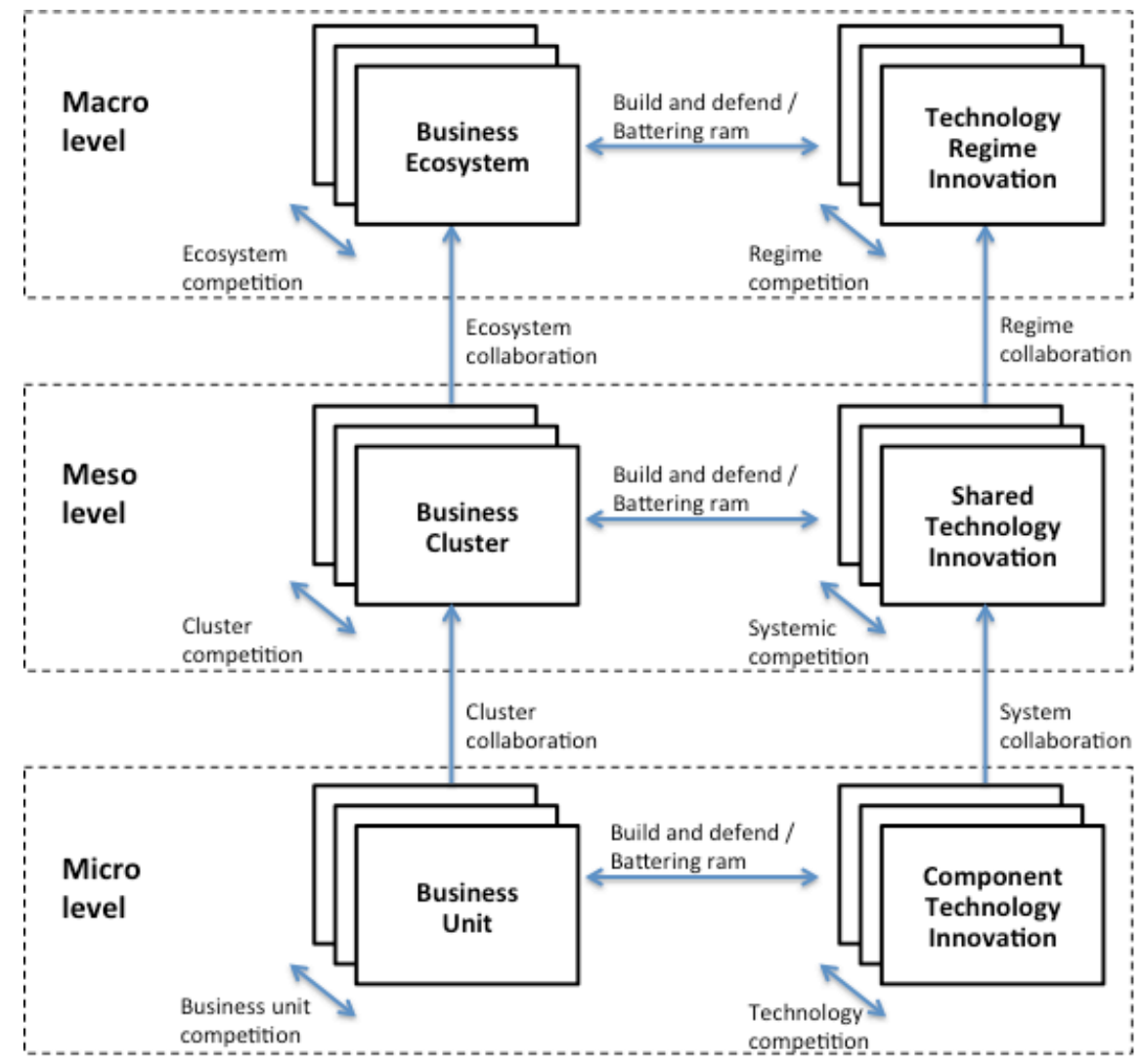

